\section{Microbial assessment of bottled drinking water of Kathmandu valley}

\author{
Timilshina $\mathbf{M},{ }^{1}$ Dahal $\mathbf{I},{ }^{1}$ Thapa $\mathbf{B}^{1,2^{*}}$ \\ ${ }^{1}$ Genesis Laboratory and Research, Kathmandu, Nepal, \\ ${ }^{2}$ Kathmandu Medical College, Kathmandu, Nepal,
}

*Correspondence to: Dr Badri Thapa, Genesis Laboratory and Research, Kathmandu, Nepal, Kathmandu Medical College, Kathmandu, Nepal, email: badri_bishal@yahoo.com, Tel. No.: (+977)-9841220108

\begin{abstract}
INTRODUCTION: Due to increased demand and consumption of bottled water in Kathmandu valley, there has been a growing concern about the microbiological quality of this product. The objective of this study was to assess the microbial contamination of heterotrophs and total coliform.
\end{abstract}

MATERIALS AND METHODS: This cross sectional study was done in randomly selected 30 different commercial brand of bottled water available in commercial market of Kathmandu valley, Nepal. Total coliform and heterotrophic bacteria were enumerated by the membrane filtration and spread plate technique, respectively.

RESULTS: $90 \% \quad(n=27)$ samples showed the heterotrophic bacterial count above the acceptable range $(<50 \mathrm{cfu} / \mathrm{ml})$ and $63.3 \%(\mathrm{n}=19)$ samples showed the total coliform count crossed the WHO guidelines (0 cfu/ml). 90\% (n=27) brands of bottled water were not safe for drinking as they exceed the heterotrophic count and/or total coliform count above the standards.

CONCLUSIONS: The presence of heterotrophs and the coliform in the bottled water is a serious concern for public health. Concerned authority should prioritize this issue and continuously monitor the quality of mushrooming bottled water manufacturers in Kathmandu valley to provide safe drinking water to the population.

KEY WORDS: Heterotrophs, Coliforms, Bottled drinking water

Article submitted 30 November. Reviewed 20 December. Author correction 22 December. Final version accepted 31 December 2012 
Water-borne diseases are among the most recent emerging and re-emerging infectious diseases, which have been the biggest health threat worldwide and they contribute between $70-80 \%$ of health problems in developing countries. ${ }^{1}$ In Nepal, morbidity and mortality rates from water borne disease are considered high particularly among children below the age of 5 years and immunocompromised individual. ${ }^{2}$ Drinking water is, however, not sterile and are contaminated by microorganisms. Microbial contamination of drinking water thus remains a major threat hence constant vigilance is indispensable especially in underdeveloped country like Nepal. ${ }^{3}$

Heterotrophic bacteria are non coliform species of bacteria that utilizes organic substance for its development. The presence of heterotrophic bacteria in drinking water is not an indication that the water presents the health risk but poses significant risk in immunocompromised individuals. Similarly, total coliform bacteria may cause special health risk for infants, young children some elderly people and especially to the immunocompromised people. ${ }^{4}$ Purpose of this study was to assess bottled drinking water for microbial contaminationby enumerating heterotrophs and total Coliforms.

The study was conducted in Genesis Laboratory and Research Centre, Kathmandu, Nepal from July 2012 to September 2012. Thirty different commercial brands of marketed bottled water (name not mentioned) samples were randomly collected from the Kathmandu valley. The samples were analyzed on the same day immediately after its delivery. When immediate analyses were not possible, the samples were preserved at $4^{\circ} \mathrm{C}$. Total coliforms were enumerated by the membrane filtration (MF) technique and culture on M-Endo agar for the detection of the total coliforms. Heterotrophic bacterial count was done by spread plate techniques on plate count agar media. Bottled water was defined as any portable water that was bottled and distributed or offered for sale and specifically intended for human consumption. ${ }^{5}$ Te criteria of WHO's bottled drinking water quality specifications world-wide was used for the interpretation of results which says that the recommend total coliform should be $0 \mathrm{cfu} / \mathrm{ml}$ and heterotrophic plate count (HPC) limits $<50 \mathrm{cfu} / \mathrm{ml}^{6}$

Out of total 30 samples, $90 \% \quad(n=27)$ had heterotrophic bacterial count above the acceptable range $(<50 \mathrm{cfu} / \mathrm{ml})$ and $63.3 \%(\mathrm{n}=19)$ samples had total coliform count above WHO guidelines $(0$ $\mathrm{cfu} / \mathrm{ml})$. Among the total 30 samples, $10 \%(\mathrm{n}=3)$

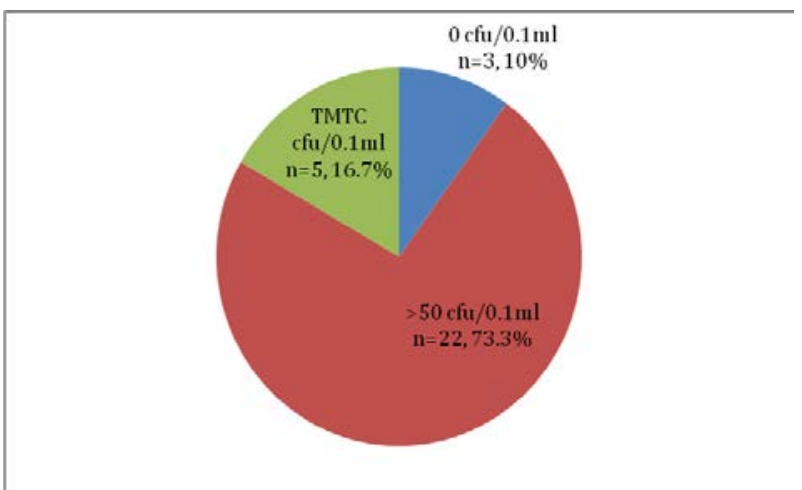

Figure 1. Heterotrophs in the bottled drinking water. $0.1 \mathrm{ml}$ of drinking water was pourded in a plate count agar and incubated over night. The heterotrophs was expressed as $\mathrm{cfu} / 0.1 \mathrm{ml}$ of drinking water.

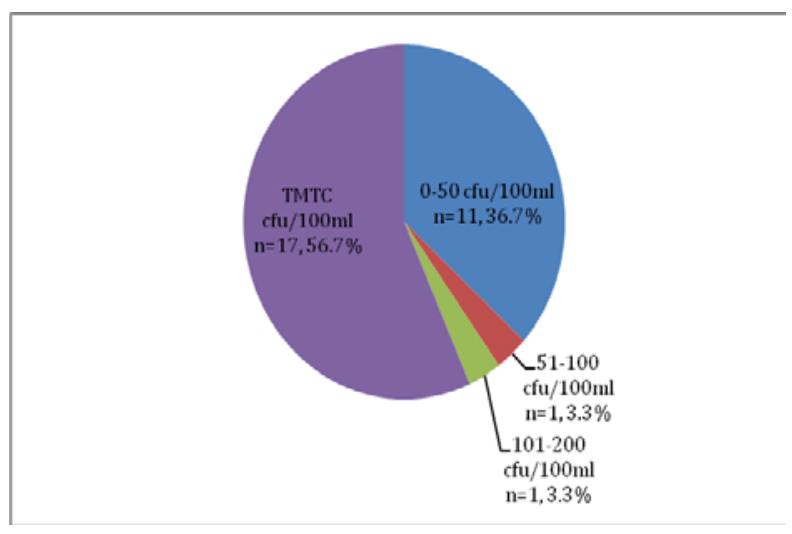

Figure 2. Total coliforms in the assessed bottled drinking water. $100 \mathrm{ml}$ drinking water was filtered through the standard membrane and membrane was inculated in a MEndo agar over night. Total coliforms was expressed as af. /1 nn ml of Aninlrine urnton

were found to have zero heterotrophs and coliforms. $16.6 \%(n=5)$ samples showed too many to count (TMTC) bacteria on both heterotrophic and total coliform count. Only $3(10 \%)$ brands of marketed bottled water were microbiologically safe and within the acceptable range of bacterial load according to the national as well as WHO guidelines. $90 \%(n=27)$ brands of bottled water were not safe for drinking as they exceed the heterotrophic count and/or total coliform count standards.

The similar percentage $(64.76 \%)$ of total coliforms were reported in samples. ${ }^{1}$ Higher $(n=73,86.90 \%)$ microbiological contamination of total coliforms of water sample has also been reported. ${ }^{7}$ Up to $91.2 \%$ $(n=52)$ of samples had total coliforms more more than the expected limits. ${ }^{8} \mathrm{~A}$ study done by Hasan et al. showed that $63 \%$ of drinking water had high level of HPC which was lower than the present 
study. ${ }^{3}$

The presence of high numbers of heterotrophic bacteria in bottled water may be due to the natural microbial flora present in the water. These bacteria can multiply after bottling, resulting in high numbers of heterotrophss. ${ }^{5}$ Another aspect is that though heterotrophs are naturally present in all aqueous environments but an abrupt increase sometimes concurrently be associated with fecal contamination. ${ }^{3}$ The presence of coliform in bottled water indicates the exposure of water to the external environment, as coliforms widely spreads in the environment or insufficient processing during bottling. Total coliform bacteria are easily destroyed during processing and their presence in water leaving a drinking water treatment plant indicates a serious treatment failure. ${ }^{9}$

The presence of heterotrophs and the coliform in the bottled water is a serious concern for public health. The child population whose immune system is weak or immunocompromised adults who consumes the bottled water rich in heterotrophs they can be seriously ill. The presence of coliform in the drinking water is an indicator of poor quality of drinking water and this can also pose the population to serious health hazards. Concerned authority should prioritize this issue and continuously monitor the quality of mushrooming bottled water manufacturers in Kathmandu valley to provide safe drinking water to the population.

CONFLICT OF INTEREST: None to declare.

FINANCIAL INTEREST: None to declare.

\section{REFERENCES}

1. Jayana BL, Prasai T, Singh A, Yami KD. Assessment of drinking water quality of MadhyapurThimi and study of antibiotic sensitivity against bacterial isolates. Nepal J Sci Technol 2009;10:167-172

2. Prasai T, Lekhak B, Joshi DR, Baral MP. Microbiological analysis of drinking water of

Kathmandu Valley. Scientific world 2007;5:112-114.

3. Hasan N, Mirani ZA, Ismat S. Bacterial indicators of risk of disease from drinking water. BALWOIS. 2010;15

4. Sharon O, Buce ID, Wayne W, Sherry W. Drinking water: Bacteria [online]. Available from: http://extension.unl.edu/publication accessed 29 November 2013.

5. Marthie ME, Walda BZ, Dobromir NP, Etienne EM. Random survey of the microbial quality of bottled water in South Africa. Water SA 2004;30:203-210.

6. World Health Organization. WHO Guidelines for Drinking-Water Quality. 2nd ed. Microbiological Methods. Geneva: Switzerland; World Health Organization; 2001. Organization; 2001.

7. Aryal J, Gautam B, Sapkota N. Drinking water quality assessment. J Nepal Health Res Counc 2012; 10:192-196.

8. Subedi M, Aryal M. Public perception about drinking jar water and its bacteriological analysis. Nepal Med Coll J 2010; 12:110-114.

9. Health Canada. Guidelines for Canadian Drinking Water Quality: Guideline Technical Document. Ottawa, Ontario: Canada; Health Canada; 2006.

\section{Citing this article}

Timilshina M, Dahal I, Thapa B. Microbial assessment of bottled drinking water of Kathmandu valley. Int J Infect Microbiol 2012;1(2);84-86. 